\title{
Editorial: How Do You Know Whence They Will Come?
}

$\mathrm{A}$ s I write this, I am putting my affairs in order at Western Michigan University, in preparation for a move to a new position at the University of Notre Dame Libraries beginning in April. At each university my responsibilities include overseeing both the online catalog and the libraries' Web presence. I mention this only because I find it interesting, and indicative of an issue with which the library profession in general is grappling, that librarians in both institutions are engaged in discussions regarding the relationship between the two.

In talking to librarians at those places and others, from some I hear sentiment for making one or the other the "primary" access point. Thus I've heard arguments that "the online catalog represents our collection, so we should use it as our main access mechanism." Other librarians state that "the online catalog is fine for searching for books in our collection, but there is so much more to find and so many more options for finding it, that we should use our Web pages to link everything together." My hunch is that probably we can all agree that there are things that an online catalog can do better than a Web site, and things that a Web site can do better than the online catalog. As far as that goes, have we ever had a primary access point (thanks to Karen Coyle for this thought)? But that's not what I want to talk about today.

The debate over a primary access point contains an invalid implicit assumption and asks the wrong question. The implicit assumption is that we can and should control how our patrons come into our systems. The question we should be asking ourselves is not "What is our primary access method?" but rather "How can we ensure that our users, local and remote, will find an avenue that enables them to meet their informational needs?"

Since at this time I'm more familiar with WMU than Notre Dame, I'll draw some examples from the former. We have "Subject Guides to Resources" on our Web site. These consist of pages put together by subject specialists that point to recommended sources, both print and electronic, local and remote, on given subjects. Students can use them to begin researching topics in a large number of subject areas. The catch is that the students have to be browsing around the Web site. If they happen to start out in the online catalog they will never encounter these gateways, because the only reference to them is on the Web site.

On the other hand, a student who stays strictly with the Web site is quite possibly going to miss a valuable resource in our library if he/she doesn't consult the online catalog, because we obviously can't list everything we own on the Web site. (Also, obviously, the Web site doesn't provide the patron with status information.) This is why we have to ask ourselves the correct question mentioned above.

What is the solution? Unfortunately I'm not any smarter than everyone else, so I don't have the answer (although I do know some folks who can help us with it: check out www.lita.org/committe/toptech/mainpage. $\mathrm{htm})$. My guess is that we'll have to work it out as a profession, possibly in collaboration with our online system vendors, and that the solution will be neither quick nor simple nor easy. There are some ad hoc moves we can make, of course, such as put links to the gateways into the catalog, and on our Web pages stress that the patron really needs to do a catalog search. The bottom line is that we have a dilemma: We can't control how people come into our electronic systems, so we can't have a "primary access point." If we try, we do harm to those who, for whatever reason, reach us via some other avenue. We need to make sure that we provide equal opportunity for all.

Dan Marmion (dmarmion@nd.edu) is Associate Director of Information Systems and Access at Notre Dame University, Notre Dame, Indiana.
PRODUCTION: ALA Production Services (Troy D. Linker, Christine S. Taylor; Angela Hanshaw, Kevin Heubusch, and Tracy Malecki), American Library Association, 50 E. Huron St., Chicago, IL 60611 .

Publication of material in Information Technology and Libraries does not constitute official endorsement by LITA or the ALA.

Abstracted in Computer $\mathcal{E}$ Information Systems, Computing Reviews, Information Science Abstracts, Library $\mathcal{E}$ Information Science Abstracts, Referativnyi
Zhurnal, Nauchnaya i Tekhnicheskaya Informatsiya, Otdyelnyi Vypusk, and Science Abstracts Publications. Indexed in CompuMath Citation Index, Computer Contents, Computer Literature Index, Current Contents/Health Services Administration, Current Contents/Social Behavioral Sciences, Current Index to Journals in Education, Education, Library Literature, Magazine Index, NewSearch, and Social Sciences Citation Index. Microfilm copies available to subscribers from University Microfilms, Ann Arbor, Michigan.

The paper used in this publication meets the mini- mum requirements of American National Standard for Information Sciences-Permanence of Paper for Printed Library Materials, ANSI Z39.48-1992.

Copyright (2000 American Library Association.

All material in this journal subject to copyright by ALA may be photocopied for the noncommercial purpose of scientific or educational advancement granted by Sections 107 and 108 of the Copyright Revision Act of 1976. For other reprinting, photocopying, or translating, address requests to the ALA Office of Rights and Permissions. 